\title{
Mycoparasitism of Rhizoctonia solani by Endophytic Chaetomium spirale ND35: Ultrastructure and Cytochemistry of the Interaction
}

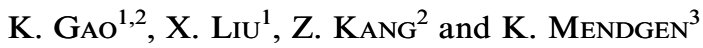 \\ Authors' addresses: ${ }^{1}$ Department of Plant Pathology, Shandong Agricultural University, Taian 271018, China; ${ }^{2}$ Northwest \\ Sci-Tech University of Agriculture and Forestry, Yangling 712100, China; ${ }^{3}$ Phytopathologie, Fachbereich Biologie, \\ Universität Konstanz, 78457 Konstanz, Germany (correspondence to X. Liu. E-mail: xgliu66@yahoo.com) \\ Received August 20, 2004; accepted March 15, 2005
}

Keywords: Chaetomium spirale, Rhizoctonia solani, mycoparasitism, ultrastructure, gold cytochemistry

\begin{abstract}
The interaction between endophytic biocontrol agent Chaetomium spirale ND35 and the soil-borne plant pathogen Rhizoctonia solani was studied by light microscopy and transmission electron microscopy (TEM), as well as further investigated by gold cytochemistry to assess the potential role of cell wall degrading enzymes (CWDEs) during the mycoparasitic process. Macroscopic observations of fungal growth in dual cultures revealed that pathogen growth inhibition occurred soon after contact with the antagonist, followed by the overgrowth of $C$. spirale on the colony of $R$. solani. The coiling of $C$. spirale around $R$. solani and intracellular growth of the antagonist in its host occurred frequently. Moreover, in advanced stage of interaction between the antagonist and the pathogen, The growth and development of $C$. spirale were associated with highly morphological changes of the host fungal cell, characterized by retraction of plasma membrane and cytoplasm disorganization. Further, TEM investigations through localization by gold immunocytochemistry showed that contact between the two fungi was mediated by an amorphous $\beta$-1,3-glucan-enriched matrix originating from cell wall of the antagonist $C$. spirale and sticking to its host surface. At the same time, the hemispherical wall appositions which were intensely labeled by the antibodies of $\beta-1$, 3 -glucan in cell wall of $R$. solani were induced to form at sites of potential antagonist entry. However, the antagonist was capable of penetrating this barrier, indicating that $\beta$-1,3-glucanases were produced during the mycoparasitic process. Localization of $\mathrm{N}$-acetylglucosamine residues (chitin) with the gold-labelled wheat germ agglutinin (WGA) implicated that chitinases might be involved in the CWD of $R$. solani in this antagonistic process as well. This report is the first evidence about mechanisms of the interactions between $C$. spirale and $R$. solani in ultrastructural and cytochemical aspects.
\end{abstract}

\section{Introduction}

Rhizoctonia species are among the most aggressive soilborne pathogens, causing losses on almost all vegetables and flowers, several field crops, turf grasses, and even perennial ornamentals, shrubs, and trees throughout the world (Agrios, 1997). Damping-off, mainly caused by $R$. solani, of seedlings in forest nurseries is one of the most serious and widely spread diseases, sometimes causing more than $70 \%$ seedling mortality (Kaushik et al., 2000). The wide host range of this pathogen as well as its ability to survive as sclerotia under adverse environmental conditions have markedly reduced the potential of crop rotation as a management strategy. In general, chemical pesticides effectively protect plants from this pathogen. However, public concerns about harmful effects of chemical pesticides on the environmental and human health, as well as the pathogens have developed resistance to the fungicides have promoted a research for safer control approach. Biocontrol is an environmental friendly and efficient alternative to chemical pesticides management of this pathogen.

Chaetomium Kunze ex Fr. is one of the major genera of ascomycetes and more than 300 Chaetomium species have been described (Reissinger et al., 2003). In the past several decades, one of the most common, C. globosum Kunze ex Fr. has received considerable attention as a potential biocontrol agent for a number of soil- and airborne plant pathogens, including $R$. solani, Pythium ultimum, Sclerotinia sclerotiorum and Venturia inaequalis, etc. The mechanisms of fungi suppression by C. globosum may be mainly based on antibiosis. In addition, mycoparasitism judged by hyphal coiling of the antagonist around $R$. solani and Alternalia brassicicola in dual cultures was observed (Andrews et al., 1983; Cullen and Andrews, 1984; Vannaeci et al., 1987; Walther and Gindrat, 1988; Di Pietro et al., 1992; Knudsen et al., 1995; Pereira and Dhingra, 1997; Monaco et al., 1998).

Chaetomium spirale ND35 is a strain of dominant endophytic fungus isolated from Populus tomentosa 
and displayed antagonistic activities against several common fruit and forest pathogenic fungi, such as Cytospora chrysosperma (teleomorph: Valsa sordida), $V$. mali and R. solani, etc. (Liu et al., 1999). Several modes of action such as antibiosis and production of extracellular lytic enzymes, mainly chitinases and $\beta$-1,3-glucanases responsible for mycoparasitism of this antagonist might play very important role in biocontrol of these diseases described above by $C$. spirale ND35. In addition, the biocontrol trials under greenhouse and field conditions have proved the biocontrol potential of strain ND35 against $V$. mali, the causal agent of apple canker (Liu et al., 1999; Gao et al., 2003, 2005). The discovery of this new biocontrol agent $C$. spirale ND35 from poplar, might open up a promising way for its practical applications in agriculture, especially for forest stem diseases management in an environmental safety way. However, one prerequisite for a rational utilization of the biological properties of a potential antagonist is a better understanding of the antagonistic mechanisms. Although hyphal interactions between Chaetomium spp. and other pathogens such as Drechslera sorokiniana (Cochliobolus sativus; Sudhamoy et al., 1999), Botrytis aclada in dead onion leaves (Kohl et al., 1997) and V. mali (Gao et al., 2005) have been studied by scanning electron microscopy (SEM); little is known about the cytological events during the mycoparasitic process. The main objective of this study was to investigate the cytochemical events of the interaction between $C$. spirale ND35 and $R$. solani through both light microscopy and transmission electron microscopy (TEM) and to delineate the potential role of CWDEs by following the pattern of chitin and $\beta$-1,3-glucan labelling in the hyphal cell walls with highly specific gold-complexed probes.

\section{Materials and Methods}

\section{Fungal isolates and cultural conditions}

The isolate of endophytic C. spirale ND35 used in this study was isolated from $P$. tomentosa and was reported as an effective antagonist of several phytopathogenic fungi (Liu et al., 1999). Rhizoctonia solani was isolated from the seedling of Pinus tablaeformis with dampingoff symptom. Both C. spirale ND35 and $R$. solani were grown on potato dextrose agar (PDA) at $25^{\circ} \mathrm{C}$ and stored at $4^{\circ} \mathrm{C}$.

\section{Dual culture tests}

A dual culture technique (Gao et al., 2002) with partial modification was used to study antagonism. A mycelial disc (5 $\mathrm{mm}$ in diameter) of C. spirale ND35 was taken from the edge of actively growing colony and placed on the surface of the PDA plate. Two days later, a mycelia disc of $R$. solani (5 $\mathrm{mm}$ in diameter) was placed $3 \mathrm{~cm}$ apart from $C$. spirale ND35 on the same PDA plate with four replicates. The mycelial discs of pathogen or antagonist on PDA alone served as controls. The plates were incubated at $25^{\circ} \mathrm{C}$. The antagonist and its host grew towards each other, and overgrowth of $R$. solani by $C$. spirale ND35 occurred by 3-4 days after inoculation of the pathogen. Mycelial samples from the interaction region were collected at 3,5 and 7 days after the pathogen inoculation and processed for electron microscopy.

\section{Light microscopy}

For the examination of light microscopy, The PDA membranes $(20 \times 20 \times 2 \mathrm{~mm})$ were cut with sterile scalpel and placed in the centre of slides. Chaetomium spirale ND35 and the pathogen were inoculated respectively in the centre of the opposite sides on the same membrane and incubated in big Petri dishes with wet filter paper at $25^{\circ} \mathrm{C}$ for 5 days. The samples were examined through the direct observation of the slides with the inoculated PDA membranes under the light microscope at 2, 3, 4 and 5 days after inoculation respectively, followed by taking micrographs with a Zeiss Axioscop microscope and MC 100 camera while mycosparasitism occurred.

\section{Transmission electron microscopy}

Mycelial samples from the interaction region, as well as samples from single cultures of each fungus on PDA were fixed in $2 \%(\mathrm{v} / \mathrm{v})$ glutaradehyde in $0.1 \mathrm{M}$ cacodylate buffer (pH 7.4) with $1 \mathrm{~mm} \mathrm{CaCl}$ and $1 \%$ $(\mathrm{w} / \mathrm{v})$ sucrose for $3 \mathrm{~h}$ at room temperature. Then samples were rinsed six times with the same buffer and postfixed with $1 \%(\mathrm{w} / \mathrm{v})$ osmium tetroxide in the same buffer for $2 \mathrm{~h}$ at room temperature. After rinsed thoroughly with $0.1 \mathrm{M}$ cacodylate buffer ( $\mathrm{pH}$ 7.4), samples were dehydrated in a graded ethanol series. Fully dehydrated samples were moved from absolute ethanol through a 1:1 mixture of ethanol and propylene oxide to pure propylene oxide. Samples were infiltrated through a series of Epon-Araldit-Mixture resin in propylene oxide, followed by embedded in moulds with fresh $100 \%$ resin and polymerized at $65^{\circ} \mathrm{C}$ for $36 \mathrm{~h}$. More than three replicate experiments were performed.

Ultrathin sections cut with a glass knife were collected on formvar-coated slot grids. After drying, the grids were contrasted with uranyl acetate and lead citrate and examined with an EM 10 CR electron microscope (Zeiss, Oberkochen, Germany) at $60 \mathrm{kV}$ or further processed for cytochemical labelling. Three samples per sampling time were examined with an average of 10 grid squares per sample.

\section{Cytochemical labelling}

To study the distribution of chitin, a linear polysaccharide of $\beta$-1,4-linked $N$-acetylglucosamine residues, WGA, a lectin with $N$-acetylglucosamine-binding specificity (Benhamou, 1989), and $10 \mathrm{~nm}$ gold-labelled WGA (purchased from British BioCell Co., Cardiff, UK) was used in this procedure. According to the method of Miosge et al. (1997) with some modification, nickel grids with ultrathin sections were first incubated on a drop of phosphate-buffered saline (PBS; $7.2 \mathrm{~mm} \mathrm{Na}_{2} \mathrm{HPO}_{4}$, $2.8 \mathrm{~mm} \mathrm{NaH}{ }_{2} \mathrm{PO}_{4}, \mathrm{pH} 7.2$ ) for $20 \mathrm{~min}$, then sections were incubated on a drop of gold-labelled WGA $(1: 20$ in PBS, $\mathrm{pH}$ 7.2) for $2 \mathrm{~h}$ at room temperature in a moist 
chamber. Sections were washed with PBS, followed by rinse with distilled water, and contrasted with uranyl acetate and lead citrate. The specificity of labelling was tested by preincubating the gold-labelled WGA in a solution of the inhibitory sugar $\mathrm{N}$-acetylglucosamine at concentrations of $0.1-0.4 \mathrm{M}$, according to the method of Winkler and Lünsdorf (2001).

\section{Immunocytochemistry}

For studying the distribution of $\beta$-1,3-glucan, the antibodies against $(1,3)-\beta$-D-glucans were used as the primary antibody. Production, characterization and specificity of the polyclonal antibody against $(1,3)-\beta$-Dglucan (no. CH-11-512, ICI, Wilmington, NC, USA) has been described by Northcote et al. (1989). The secondary antibodies [goat antirabbit, immunoglobulin $\mathrm{G}$ (IgG)] coupled to $10 \mathrm{~nm}$ gold particles were purchased from Aurion company (Wageningen, the Netherlands).

According to the amended method of Kang and Buchenauer (2002, 2003), immunogold labelling was carried out as follows: (i) nickel grids with ultrathin sections were placed on water for $1 \mathrm{~min}$ in a high humidity chamber; (ii) incubation of ultrathin sections with blocking solution containing $1 \%$ bovine serum albumin (BSA)-C in Tris-buffered saline (TBS; $10 \mathrm{~mm}$ Tris- $\mathrm{HCl}, 150 \mathrm{~mm} \mathrm{NaCl}, \mathrm{pH}$ 7.4) for $20 \mathrm{~min}$; (iii) incubation of the sections with the primary antibody diluted at 1:200 in blocking solution for $2 \mathrm{~h}$ at room temperature; (iv) washing 10 times with TBS; (v) incubation of the sections with the secondary antibody diluted at $1: 20$ in TBS; (vi) rinsing with TBS, followed by a distilled water rinse. After contrasting with uranyl acetate and lead citrate, the sections were examined with a Zeiss EM $10 \mathrm{CR}$ electron microscope at $60 \mathrm{kV}$. Three replicate experiments were performed. The specificity of antibody labelling for the immunolabelling of $\beta$-1,3-glucan was determined by replacing the primary antibody with buffer, according to the method of Rodriguez-Galvez and Mendgen (1995).

\section{Results \\ Fungal growth in dual cultures and light microscopy observations}

In Petri dish dual cultures, the first apparent contact between $C$. spirale ND35 and its host $R$. solani occurred within 2-3 days after pathogen inoculation, followed by occurring pathogenic growth inhibition soon after contact with the antagonist, and $C$. spirale overgrowth on the colony of $R$. solani, accompanied by retraction of the pathogenic aerial mycelium. By 8 days after inoculation, $C$. spirale began to produce a large number of perithecia.

Chaetomium hyphae, easily recognized, because of their smaller diameter, and its mycelial growth on or along the hyphae of the pathogen, even penetration can be frequently observed under light microscopy. The observations under light microscope showed that $C$. spirale ND35 densely coiled around the hypha of $R$. solani (Fig. 1a). And the intracellular growth in the hyphae of $R$. solani was observed as well (Fig. 1b). At
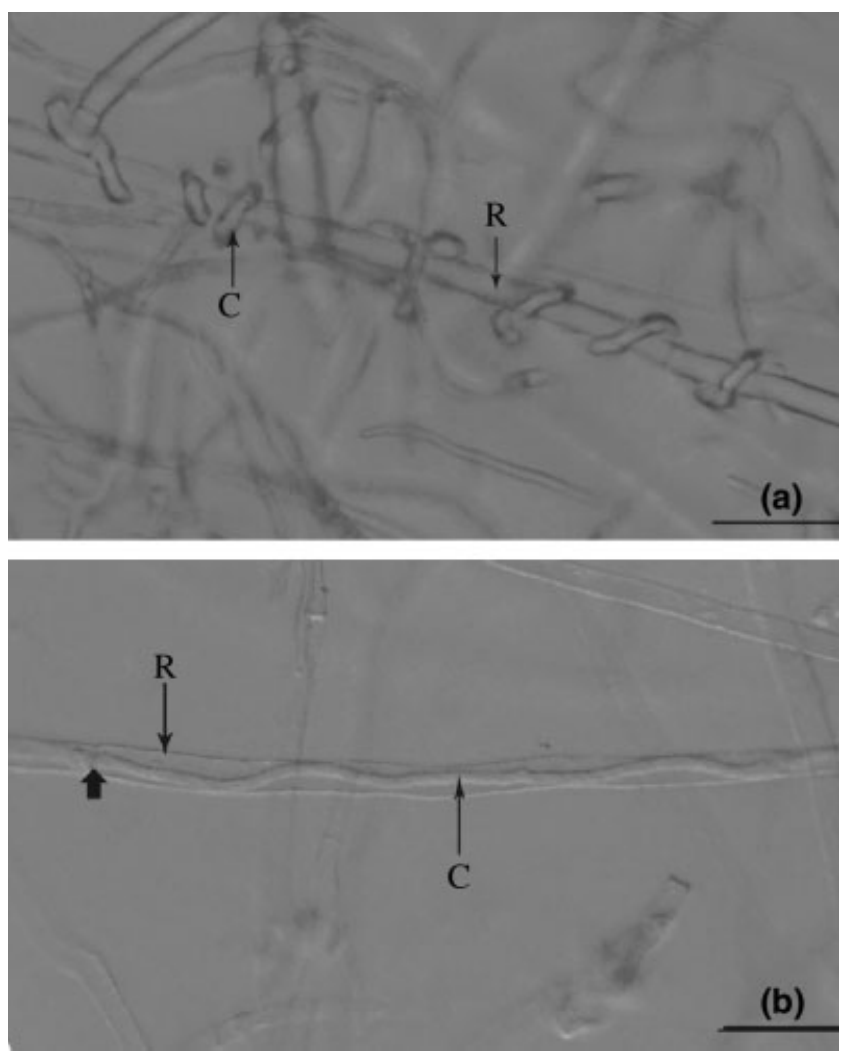

Fig. 1 Light micrographs of the hyphal interacting between Chaetomium spirale (C) and Rhizoctonia solani (R) in dual cultures. (a) Three days after the pathogen inoculation, the Chaetomium hyphae (C) densely coiled around hyphae of $R$. solani (R). (b) Five days after the pathogen inoculation, a Chaetomium hypha (C) grew intracellularly in the cell of $R$. solani $(\mathrm{R})$ and penetrated through the septum of host cell (arrowhead). (a and b) Bar $=5 \mu \mathrm{m}$

a later stage of the antagonistic process, several hyphae of $R$. solani were strongly degraded and cytoplasm of pathogenic hyphae became to empty, as well as pathogenic hyphae appeared as abnormally shaped, empty pleiomorphic shells (data not shown). To gain a better insight into the pattern of interaction between $C$. spirale ND35 and $R$. solani, more precise information at the ultrastructural level was needed.

\section{TEM observations}

More detailed pictures of the penetration structures in parasitizing process of antagonist was obtained through TEM observations of ultrathin sections. When grown in single culture, $R$. solani showed similar ultrastructure to the results of observations from Benhamou and Chet (1993) and Carisse et al. (2001). Cells were delimited by thick and dark cell walls. They contained a dolipore septum and a dense polyribosome-enriched cytoplasm in which a large number of organelles including mitochondria, vacuole, endoplasmic reticulum, nuclei and lipid bodies (Fig. 2a).

Examination of ultrathin sections from the interaction region of 3-day-old dual cultures demonstrated that hyphae of $C$. spirale, easily recognized by their smaller diameter, frequently encircled hyphae of $R$. solani (Figs 2b, 3d and 4d) and established close contact 
Fig. 2 Transmission electron micrographs of Chaetomium spirale (C) hyphae interacting with cells of Rhizoctonia solani (R) in dual cultures. (a) Hyphae of $R$. solan (R) in single culture showed a fine ultrastructure with a doipore septum (Do) and dense polyribosome-enriched cytoplasm in which a large number of organelles including mitochondria (M) and vacuole $(\mathrm{V} ;$ bar $=2 \mu \mathrm{m})$. (b and c) Three days after inoculation: (b) a hypha of Chaetomium (C) encircled a cell of $R$. solani $(\mathrm{R}$; bar $=2.5 \mu \mathrm{m}$ ); (c) two hyphae of Chaetomium (C) was infecting a cell wall of $R$. solani $(\mathrm{R})$ and inducing wall apposition (WA). A Chaetomium hypha formed a penetration peg (PP) and another appeared to cause stratification of wall apposition (arrow; bar = $2 \mu \mathrm{m}$ ). (d and e) Five days postinoculation: (d) a hypha of Chaetomium (C) penetrated into and grew within a cell of $R$. solani (R; bar $=2.5 \mu \mathrm{m})$; (e) a hypha of Chaetomium (C) grew in a cell of $R$. solani $(\mathrm{R} ;$ bar $=2.5 \mu \mathrm{m})$. (f) By 7 days after inoculation, because of parasitizing of $C$. spirale (C) a cell of $R$. solani $(\mathrm{R})$ showed signs of pronounced alteration characterized by plasma membrane retraction (arrowheads) and cytoplasm disorganization (bar $=1 \mu \mathrm{m})$
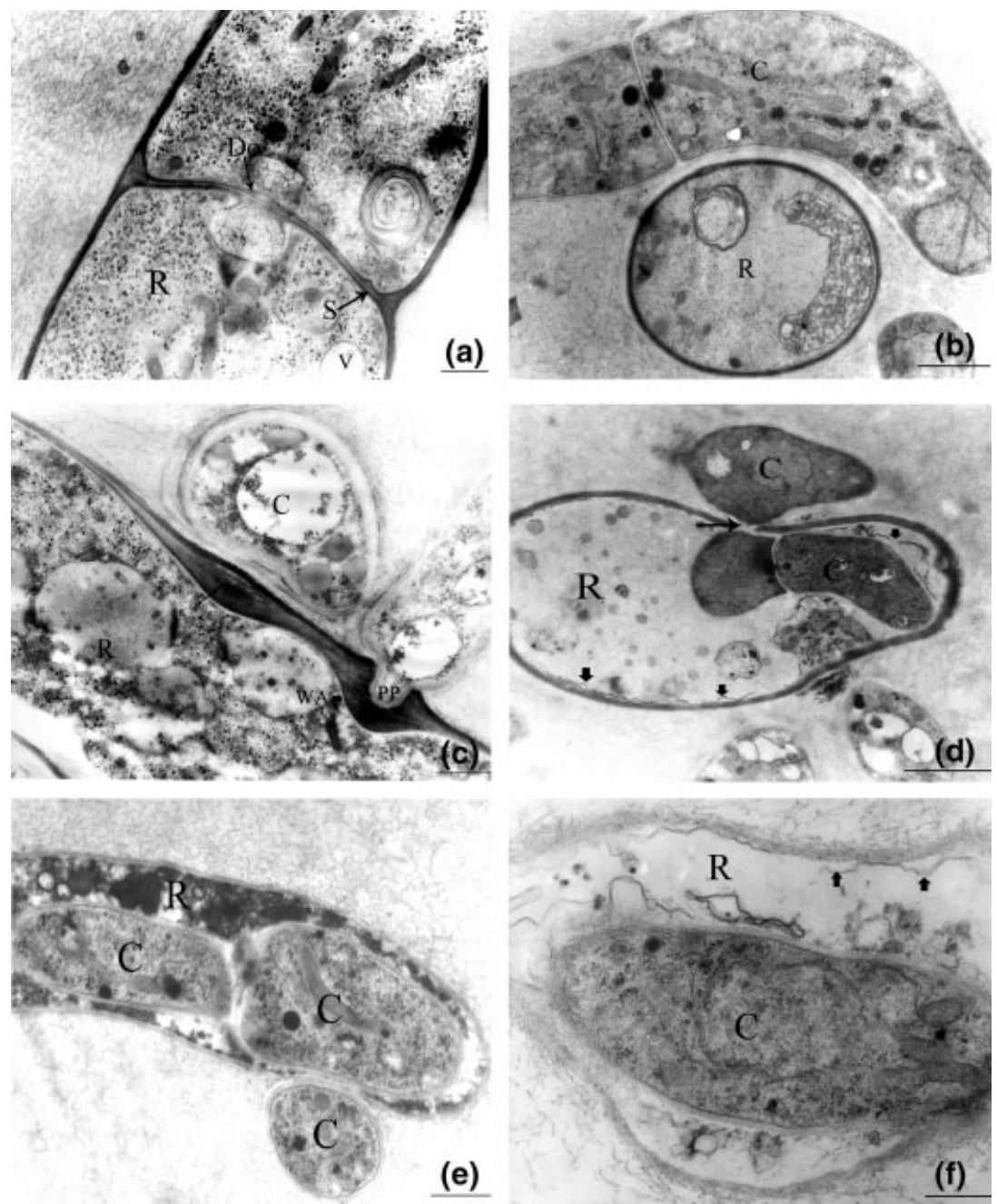

with the host cells. At the same time Chaetomium hyphae formed penetration pegs and induced the formation of wall appositions in the hyphal cells of $R$. solani (Fig. 2c). The thickened wall layers appeared splitting signs (Fig. 2c, arrow). Sometimes two to three potential penetration sites were observed in one cell of $R$. solani (Figs $2 \mathrm{c}$ and $3 \mathrm{~d}$ ). Investigations of mycelial samples collected from the interaction region 5 days after inoculation showed that the antagonist with intact ultrastructure intracellularly grew (Fig. 2d,e) in pathogenic cells after invading the Rhizoctonia hyphae, and went through the septa to extend continuously (Fig. 3h). By 7 days postinoculation, the cytoplasm and protoplast membrane (arrowheads) in some hyphal cells of $R$. solani were markedly disorganized. In most cases, organelles were no longer discernible in the highly altered cytoplasm (Fig. 2f).

\section{Cytochemical localization of $N$-acetylglucosamine residues (chitin)}

Ultrathin sections from individual colonies of either $C$. spirale ND35 (Fig. 3a) or R. solani (Fig. 3b) were incubated with gold-labelled WGA for localizing $\mathrm{N}$-acetylglucosamine residues (chitin). With both fungi, an intense labelling was specifically associated with the cell wall. In contrast, cytoplasm, organelles and vacuoles were nearly devoid of labelling. In control test, no labelling was found over the cell walls of fungi (Fig. 3c). Three days postinoculation with the pathogen, Chaetomium encircled the hyphal cell of $R$. solani was frequently observed, moreover three penetration pegs synchronously penetrated into the same cell and induced the formation of wall appositions (Fig. 3d). Observations at a higher magnification showed the early penetration and formation of penetration peg of the Chaetomium hypha, as well as the formation of hemispherical wall appositions and a slight retraction of the plasma membrane (PM) from the wall by $R$. solani. The localization situation of some gold particles over them also can be observed (Fig. 3e, arrowheads). Examination of 20 ultrathin sections from the interaction region of 3-day-old dual cultures also revealed the contact of hyphal cell wall between $\mathrm{Cha}$ etomium and its host (Fig. 3f). At a close observation, the PM of pathogenic cell showed slightly retraction and a decrease in the electron density of the outermost wall layer. Interestingly, cell wall layers of both the antagonist and the pathogen appeared diffuse when in close contact. Incubation of these sections with the gold-labelled WGA resulted in the deposition of gold 

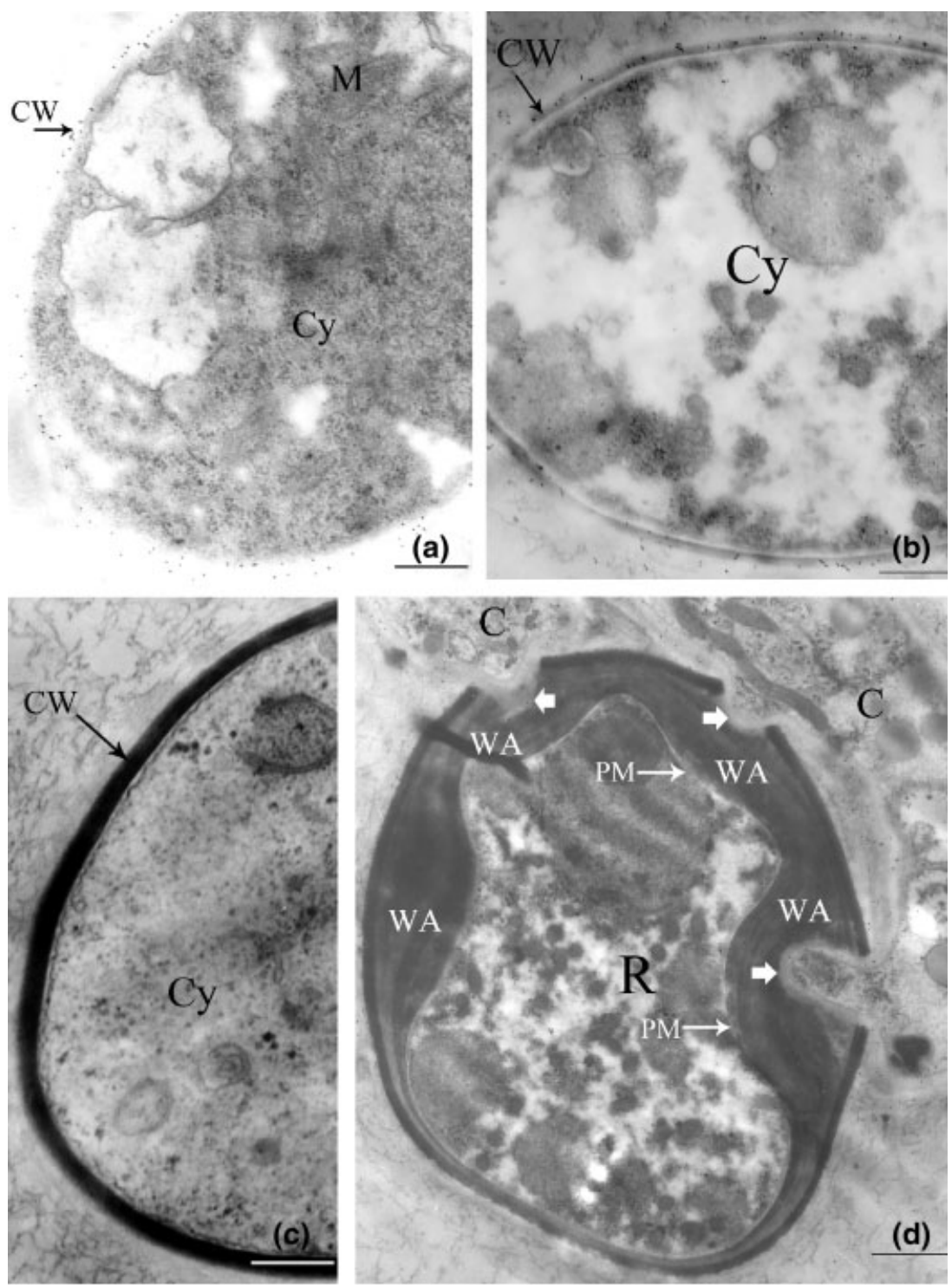

Fig. 3 Transmission electron micrographs of Chaetomium spirale and Rhizoctonia solani in single cultures or dual cultures. Labelling of chitin with the gold-labelled wheat germ agglutinin (WGA). (a and b) A regular deposition of gold particles (arrows) occurred over the hyphal cell walls $(\mathrm{CW})$ of $C$. spirale (a) and $R$. solani (b) grew in pure culture. Cytoplasm (Cy) and organelles such as mitochondria (M) were unlabeled (bar $=2 \mu \mathrm{m})$. (c) Negative control test: no labelling was found over the hyphal cell walls $(\mathrm{CW})$ of $R$. solani (bar $=2 \mu \mathrm{m})$. (d-f) Three days after inoculation: (d) a hypha of Chaetomium (C) was encircling a cell of $R$. solani (R), producing three penetration pegs (arrowheads), as well as penetrating into the same cell and inducing the formation of wall appositions (WA), accompanied a slight retraction of plasma membrane $(\mathrm{PM}$; bar $=2 \mu \mathrm{m})$; (e) portion of (d) at a higher magnification showed an early penetration of the Chaetomium hypha, formation of penetration peg (PP) and hemispherical WA, as well as a slight retraction of plasma membrane (PM; bar $=1 \mu \mathrm{m})$; (f) the hyphal cell wall of Chaetomium (C) contacted with the cell wall of $R$. solani (R) was showing slightly retraction of PM (arrowhead). Gold particles were significantly reduced over the cell wall of $R$. solani $(\mathrm{bar}=0.5 \mu \mathrm{m})$. (g) Five days postinoculation, the hyphal cell wall of Chaetomium $(\mathrm{C})$ did not directly contact with the cell wall of $R$. solani $(\mathrm{R})$. However, the cell wall of $R$. solani showed signs of a decrease in the electron density of the outermost wall layer (arrow) and a few of gold particles over it $(\mathrm{bar}=1 \mu \mathrm{m})$. (h) Two hyphae of Chaetomium (C) grew in a cell of $R$. solani (R) and one of them was passing the septum (arrowhead) of $R$. solani. Some gold particles were observed over the cell wall (arrows) of Chaetomium and a few of gold particles were found over the wall and septum (arrowhead) of $R$. solani $(\mathrm{bar}=2.5 \mu \mathrm{m})$

particles over cell walls of both fungi. However, gold particles were irregularly distributed over the cell walls of $R$. solani (Fig. 3f). Five days postinoculation, although hyphal cell wall of Chaetomium did not directly contact with $R$. solani, the cell wall of $R$. solani also showed signs of a decrease in the electron density of the outermost wall layer and a few of gold particles over it (Fig. 3g, arrow). Two hyphae of Chaetomium grew in one cell of $R$. solani and one of them was pass- ing the septum of $R$. solani were also observed (Fig. 3h). Some gold particles were found over the cell wall of Chaetomium, and a few of gold particles were observed over the wall and septum of $R$. solani. Hyphae of the antagonist ramified so extensively in host hyphae that it was difficult to delineate some free space in the area that was originally occupied by the host cytoplasm (Fig. 3h). Such a massive colonization frequently resulted in a strong mechanical pressure 

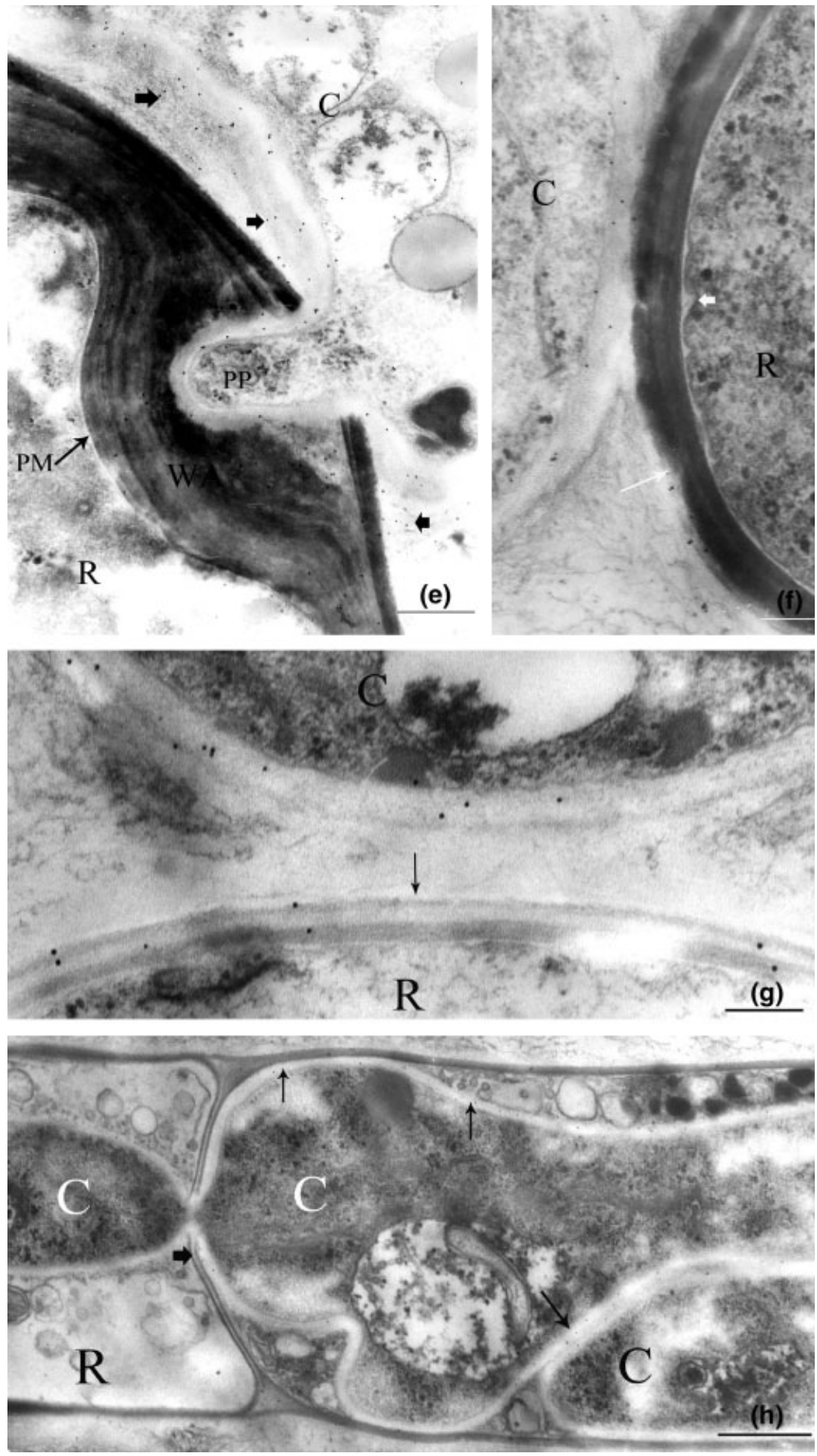

Fig. 3 Continued

against the host hyphal cell walls, ultimately leading to an apparent bursting of the host hyphae.

\section{Immunocytochemical localization of $\boldsymbol{\beta}$-1,3-glucan}

Gold particles were predominantly associated with the hyphal cell walls of $C$. spirale (Fig. 4a) and $R$. solani (Fig. 4b) grown in single cultures. Three days after inoculation with the pathogen, cells of $R$. solani were encircled by hyphae of Chaetomium and produced wall appositions (Fig. 4c,d). A large number of gold particles were distributed evenly over the cell walls of Chaetomium and pathogen except at sites of potential penetration by the antagonist and slight alterations occurred over the cell wall of pathogen (Fig. 4d). A 


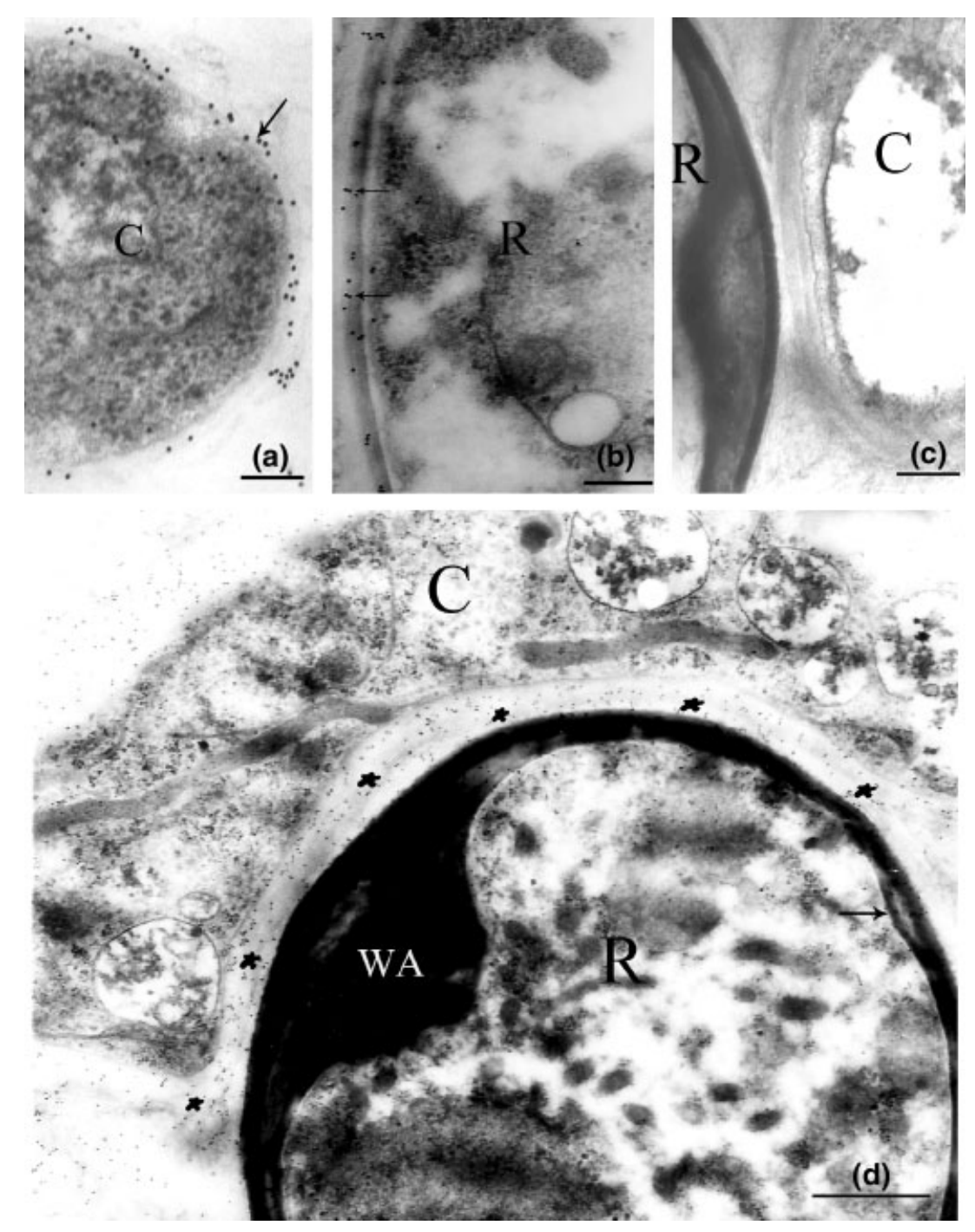

Fig. 4 Transmission electron micrographs of a single culture of Chaetomium spirale orRhizoctonia solani and dual cultures between C. spirale and $R$. solani. The immunolabelling of $\beta$-1,3-glucans with the antibodies of $\beta$-1,3-glucan. (a and $\mathrm{b}$ ) Gold particles (arrows) were mainly observed over the cell wall of a $C$. spirale hypha $(\mathrm{a} ; \mathrm{bar}=0.5 \mu \mathrm{m})$ and a $R$. solani hypha $(\mathrm{b} ; \mathrm{bar}=1 \mu \mathrm{m})$ grown in single culture. (c) Negative control test: no gold labelling was found over the hyphal cell walls $(\mathrm{CW})$ of $R$. solani and $C$. spirale (bar $=1 \mu \mathrm{m})$. (d and e) Three days after inoculation: (d) a cell of $R$. solani (R) were encircled by a hypha of Chaetomium (C) and produced a wall apposition (WA). More gold particles were distributed evenly over the cell walls of Chaetomium and pathogen (stars) except at sites of potential penetration by the antagonist and slight alteration area (arrow) over the hyphal cell wall of pathogen (bar $=2 \mu \mathrm{m}$ ); (e) at higher magnification, picture showed that contact between antagonist and pathogen was mediated by an amorphous matrix intensely labelled with the antibodies of $\beta$-1,3-glucan (stars). A penetration peg (PP) of Chaetomium hypha (C) was penetrating into a wall apposition in the hyphal cell of $R$. solani $(\mathrm{R} ; \mathrm{bar}=1 \mu \mathrm{m})$. (f) Five days postinoculation, the cell of $R$. solani $(\mathrm{R})$ was parasitized by two Chaetomium hyphae (C). The markedly disorganized cytoplasm and some digested wall areas were visible (arrowheads). Gold particles were mainly distributed over the cell walls of antagonist and pathogen $(\mathrm{bar}=2 \mu \mathrm{m})$. (g) Seven days after inoculation, although hyphae of Chaetomium (C) did not directly contact with the cell wall of $R$. solani (R), plasma membrane (arrow) was already retracted, and cytoplasm was highly disorganized (bar $=1.5 \mu \mathrm{m}$ ). (h) At an advanced stage of the interaction, the cell wall of a $R$. solani $(\mathrm{R})$ contacting with hypha of Chaetomium was degraded strongly and cytoplasm and all organelles were highly damaged $(\mathrm{bar}=1 \mu \mathrm{m})$

close examination revealed that contact between the two fungi was mediated by an amorphous matrix labelled intensely with the antibodies of $\beta$-1,3-glucan. This $\beta$-1,3-glucan-enriched matrix appeared to originate from the antagonist cell wall and to stick to its host surface (Fig. 4e). Penetration pegs of Chaetomium hyphae penetrated into the hemispherical wall appositions in hyphal cells of $R$. solani. More gold particles were observed over the cell walls of penetration pegs and Chaetomium hyphae as well as those areas near the invaginated PM on wall appositions in the hyphal cell of $R$. solani. However, a few of gold particles were found along the channel of penetration over the wall appositions in the cell of $R$. solani (Fig. 4e). By 5 days after inoculation, the cells of $R$. solani were parasitized by two Chaetomium hyphae (Fig. 4f). Pathogenic cytoplasm was pronouncedly disorganized and some digested wall areas were visible (arrowheads). Gold particles were mainly distributed over the cell walls of antagonist and pathogen. Some gold particles were also scattered over the cytoplasm (Fig. 4f). Seven days postinoculation, although hyphae of Chaetomium did 

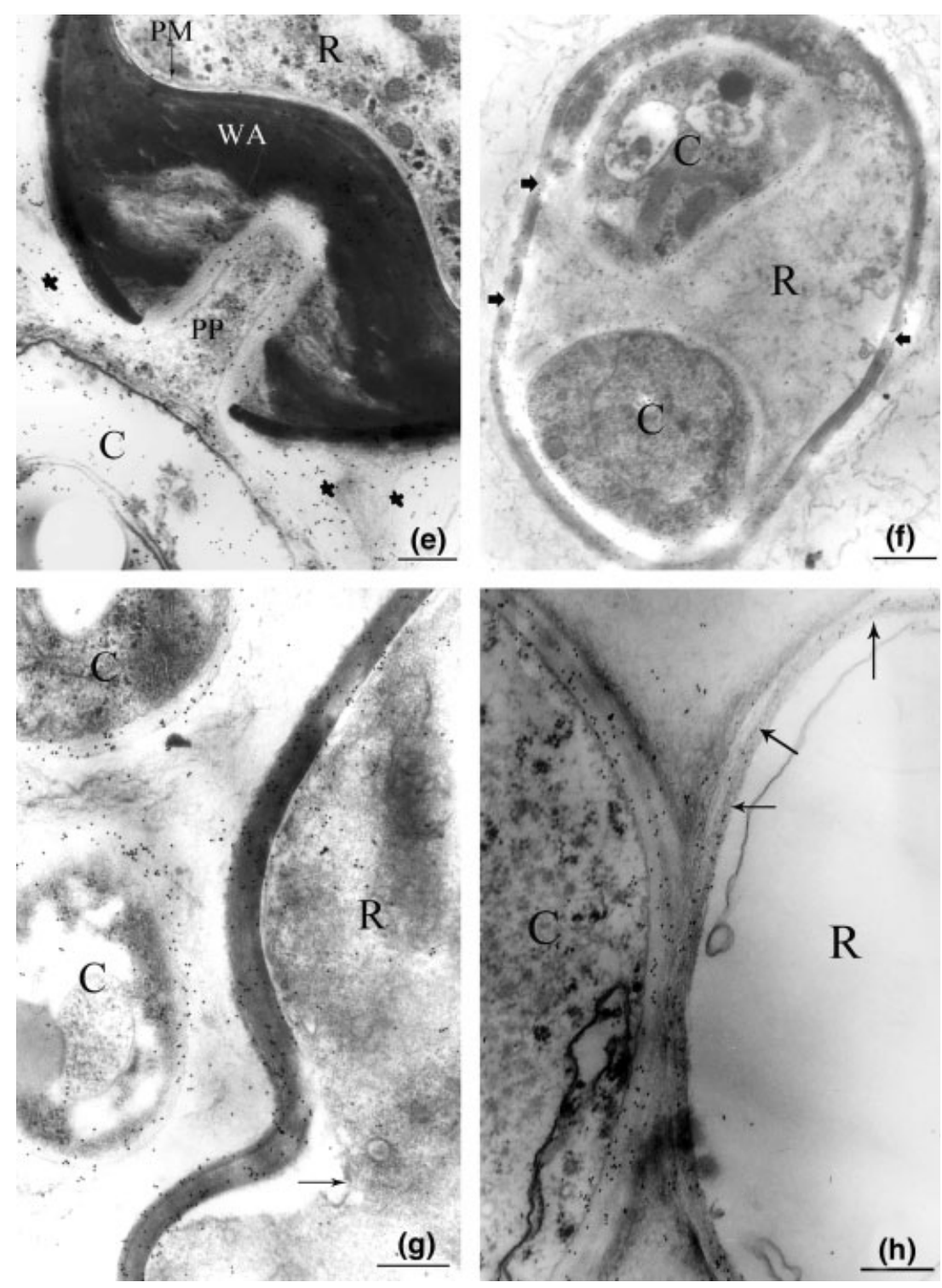

Fig. 4 Continued

not directly contact with the cell wall of $R$. solani, but PM was already retracted, and cytoplasm was highly disorganized (Fig. 4g). At a more advanced stage of the interaction, the cell walls of $R$. solani contacting with hyphae of Chaetomium were seriously degraded as well as cytoplasm and all organelles were markedly damaged (Fig. 4h).

All control tests performed on sections of samples collected from the interaction region yielded negative results (Fig. 4c).

\section{Discussion}

The ability to produce lytic enzymes has been showed to be a crucial property of the mycoparasitic fungi. Most phytopathogenic fungi have cell wall that contain chitin as a structural backbone arranged in regularly ordered layers and laminarin ( $\beta-1,3$-glucan) as a filling material arranged in an amorphic manner. The other minor cell wall components are proteins and lipids (Chernin and Chet, 2002). The CWDEs such as chitinases, glucanases and protease, are not only involved in the destruction of the host cell wall; they may also play a role during the initial stages of mycoparasitism, because oligosaccharides generated by CWDEs partially degrading the cell walls of the host may act in turn as elicitors for the general antifungal response of mycoparasitic fungi (Chet and Chernin, 2002).

Our studies demonstrated that $R$. solani is highly vulnerable to an attack by the endophytic antagonist C. spirale ND35. The present cytochemical investigations were undertaken to gain a better insight into the cellular and molecular mechanisms in the process of mycoparasitism. Our results provided evidence that early recognition events that mediated by a $\beta$-1,3-glucan-enriched amorphous matrix originating from C. spirale ND35 triggered the firm binding of the antagonist to the host cell surface, leading to a subsequent programme of specific responses, such as 
adhesion and penetration of the antagonist in $R$. solani, precede pathogenic cell alterations, including the formation of wall appositions, cell wall degradation, plasmalemma and cytoplasm disorganization. To our knowledge, the present results provide the first ultrastructural and cytochemical evidence of the interactions between $C$. spirale ND35 and $R$. solani in the mycoparasitic process.

Macroscopic observations of fungal development in dual cultures as well as light microscopy examinations of the interaction region indicated that growth inhibition and structural alterations of the pathogen appeared soon after contact with $C$. spirale ND35. These results are similar to those reports for Trichoderma harzianum (Benhamou and Chet, 1993, 1996, 1997) and P. oligandrum (Benhamou et al., 1999) as well as Microsphaeropsis sp. (Carisse et al., 2001).

TEM observations of the interaction region between the two fungi exhibited that hyphae of Chaetomium encircled and established close contact with the host mycelium. These observations provided support to the assumption that the outcome of the interactions was likely determined by early recognition events. Positive correlations between surface-associated components and recognition events in microbial interactions often have been suggested (Chet, 1987; Benhamou and Chet, 1993) and considered to be key determinants in the outcome of a given interaction. Although early studies pointed to a possible role for lectin in the recognition process, Inbar and Chet (1992) proved the role of lectins in Trichoderma mycoparasitism. Utilizing lectin-coated nylon fibres through biomimics, T. harzianum coiled around the fibres in a way similar to that observed with host hyphae. However, whether such a phenomenon plays a role in the initial recognition between $C$. spirale ND35 and $R$. solani needs further investigation.

With regard to the mechanisms of early recognition and contact between the antagonist and pathogen, there have been some different research results from previous studies on different antagonist and fungal host partners. Benhamou and Chet (1993) observed the interaction between $T$. harzianum and $R$. solani and thought that cells of Trichoderma encircled and established close contact with the host mycelium appeared to be mediated by a fine, external matrix originating from $R$. solani hyphae. The polysaccharidic nature of this fine matrix layer was judged with the gold-complexed Ricinus lectin. The occurrence of significant amounts of galactose residues in the external matrix of $R$. solani suggested that receptors with galactose-binding affinity were present at the cell surface of Trichoderma. Because lectins are sugar-binding proteins, a Trichoderma lectin may be responsible for the binding of the galactose-rich matrix of $R$. solani. In addition, observations of the interaction region between $P$. oligandrum and Fusarium oxysporum f. sp. radicis-lycopersici made by Benhamou et al. (1999) showed that contact apparently was mediated by a fine, external matrix originating from the Fusarium hyphae. The occurrence of a significant amount of chi- tin residues in this matrix suggested that receptors with $N$-acetylglucosamine-binding affinity were present at the cell surface of $P$. oligandrum. A similar interfacial material was not detected in the interactions between the antagonist $P$. oligandrum and $P$. ultimum, $P$. aphanidermatum, or $R$. solani, although intense coiling and adhesion of $P$. oligandrum to the host hyphae could be seen. However, Carisse et al. (2001) made observations of the interaction between Microsphaeropsis sp. and $R$. solani. They found that the outcome of the interaction was likely determined by early recognition events often mediated by an amorphous matrix originating from the antagonist, Microsphaeropsis sp., but not the pathogen. And a substantial amount of chitin occurred in this matrix suggests that receptors with $N$-acetylglucosamine-binding affinity are present at the cell surface of $R$. solani. Their these findings are almost in accordance with our investigations on acting mode of $C$. spirale ND35 and $R$. solani, except the occurrence of a significant amount of $\beta$-1,3-glucan instead of chitin in this matrix suggests that receptors with $\beta$-1,3-glucan-binding affinity should be present at the cell surface of $R$. solani hyphae.

One of the most striking features of the interaction between $C$. spirale ND35 and $R$. solani was the abnormal formation of wall appositions at sites of potential antagonist entry. This is similar to the observations on interaction between Microsphaeropsis sp. and $R$. solani made by Carisse et al. (2001). Interestingly, the formation of such structural barriers at strategic sites may reflect a defence reaction elaborated by the pathogen in response to antagonist attack. Such a phenomenon, abundantly described in host plant-pathogen interactions (Benhamou et al., 1994; Benhamou and Lafontaine, 1995; Belanger et al., 2003) and induction of defense-related reaction in plant root by non-pathogenic fungi (Benhamou et al., 1997, 2002; Yedidia et al., 1999; Benhamou and Garand, 2001), but little is known in fungus-fungus interactions. The hemispherical wall appositions at sites of potential antagonist entry in hyphal cells of $R$. solani were intensely labelled by the antibodies of $\beta$-1,3-glucan. This suggested that the wall appositions were mainly composed of $\beta$-1,3-glucans and might function as defence barriers-like callose in plant cells.

Whatever the role played by the wall appositions, the antagonist revealed the ability to penetrate cells of pathogen, and indicated the potential of $C$. spirale ND35 to produce extracellularly hydrolytic enzymes such as chitinases and $\beta$-1,3-glucanase in the process of penetrating into cell walls of pathogen through penetration pegs.

Our earlier investigations demonstrated that at least an exo- $\beta$-1,3-glucanase and a chitinase from $C$. spirale, induced by cell wall of $R$. solani ND35 were detected both in culture filtrate and on sodium dodecyl sulphate polyacrylamide gel electrophoresis (SDS-PAGE). Chaetomium spirale ND35 penetrating the host mycelia by partially degrading its cell wall and holes in the penetration site on the host mycelia in dual culture with 
$V$. mali were observed by SEM, it revealed that these CWDEs were involved in mycoparasitic attack on the host, as well as in growth and differentiation of itself. Moreover, it is likely that a coordinated action of chitinases and $\beta$-1,3-glucanase is a prerequisite to an effective cell wall disruption of the pathogenic fungi (Gao et al., 2005).

On the contrary, antibiosis might be a key determinant of antifungal activity of $C$. spirale ND35. We conducted extraction and purification of antibiotics from C. spirale ND35 in a primary experiment and proved growth inhibition of antibiotics against $V$. sordida and $V$. mali respectively in vitro (unpublished data). Schirmböck et al. (1994) confirmed that the synergism between CWDEs and antibiotics was also an important feature of the antagonistic process in the T. harzianum$B$. cinerea interaction. Compared with the previous results of Elad et al. (1980), Di Pietro et al. (1993) and Schirmböck et al. (1994), we could visualize that both hydrolytic enzymes and antibiotics could be involved in the antagonistic action of $C$. spirale ND35 against $R$. solani, as well as their synergistic action might be much more important, according to the hypothetical model (Lorito et al., 1996) that the degrading of the cell wall by the hydrolytic enzymes should facilitate the rate of diffusion of the antibiotic towards the receptor on the cell membrane. In turn, the antibiotic activity on some membrane-associated functions, such as chitin synthesis, should reduce the synthesis and repairing of the cell wall, thus facilitating the action of the CWDEs. The synergistic interaction between fungal CWDEs and antibiotics need to be further investigated to improve the biocontrol efficacy of the strain $C$. spirale ND35.

In conclusion, our results provide evidence that C. spirale ND35 has the potential to become a promising biocontrol agent against a wide range of both soilborne and air-borne phytopathogenic fungi.

\section{Acknowledgements}

This work was supported by the National Natural Science Foundation of China (NSFC), Grant No. 30100143. The authors thank all staffs in Lehrstuhl für Phytopathologie, Fakultät für Biologie der Universität Konstanz, Germany for kindly help. The first author is grateful to the China Scholarship Council (CSC) for providing a scholarship. Thanks are due to Dr B. Metzler (Forstliche Versuchs und Forschungsanstalt, Baden-Wuerttemberg, Germany) for identification the isolate of $C$. spirale ND35 as well.

\section{References}

Agrios GN. Parasitism and disease development. In: Agrios GN (ed.), Plant Pathology, 4th edn, San Diego, USA, Academic Press, 1997, pp. 290-395.

Andrews JH, Berbee FM, Nordheim EF. (1983) Microbial antagonism to the imperfect stage of the apple scab pathogen, Venturia inaequalis. Phytopathology 73:228-234.

Belanger RR, Benhamou N, Menzies JG. (2003) Cytochemical evidence of an active role of silicon in wheat resistance to powdery mildew (Blumeria grgaminis f. sp. Tritici). Phytopathology 93:402-412.

Benhamou N. Preparation and application of lectin-gold complexes. In: Hayat MY (ed.), Colloidal Gold: Principles, Methods and Applications, New York, Academic Press, 1989, pp. 95-143.

Benhamou N, Chet I. (1993) Hyphal interactions between Trichoderma harzianum and Rhizoctonia solani: ultrastructure and gold cytochemistry of the mycoparasitic process. Phytopathology 83:1062-1071.

Benhamou N, Chet I. (1996) Parasitism of sclerotia of Sclerotium rolfsii by Trichoderma harzianum: ultrastructural and cytochemical aspects of the interaction. Phytopathology 86:405-416.

Benhamou N, Chet I. (1997) Cellular and molecular mechanisms involved in the interaction between Trichoderma harzianum and Pythium ultimum. Appl Environ Microbiol 63:2095-2099.

Benhamou N, Garand C. (2001) Cytological analysis of defenserelated mechanisms induced in pea root tissues in response to colonization by nonpathogenic Fusarium oxysporum Fo47. Phytopathology 91:730-740.

Benhamou N, Lafontaine PJ. (1995) Ultrastructural and cytochemical characterization of elicitor-induced responses in tomato root tissues infected by Fusarium oxysporum f. sp. radicis-lycopersici. Planta 197:89-102.

Benhamou N, Lafontaine PJ, Nicole M. (1994) Induction to systemic resistance to Fusarium crown and root rot in tomato plants by seed treatment with chitosan. Phytopathology 84:1432-1444.

Benhamou N, Rey P, Cherif M, Hockenhull J, Tirilly Y. (1997) Treatment with the mycoparasite Pythium oligandrum triggers induction of defense-related reactions in tomato roots when challenged with Fusarium oxysporum f. sp. radicis-lycopersici. Phytopathology 87:108-122.

Benhamou N, Rey P, Pichard K, Tirilly Y. (1999) Ultrastructural and cytochemical aspects of the interaction between the mycoparasite Pythium oligandrum and soilborne plant pathogens. Phytopathology 89:506-517.

Benhamou N, Garand C, Goulet A. (2002) Ability of nonpathogenic Fusarium oxysporum stain Fo47 to induce resistance against Pythium ultimum infection in cucumber. Appl Environ Microbiol 68:4044-4060.

Carisse O, Bassam SC, Benhamou N. (2001) Effect of Microsphaeropsis sp. strain $\mathrm{P} 130 \mathrm{~A}$ on germination and production of sclerotia of Rhizoctonia solani and interaction between the antagonist and the pathogen. Phytopathology 91:782-791.

Chernin L, Chet I. Microbial enzymes in the biocontrol of plant pathogens and pests. In: Dick RP, Burns RG (eds), Enzyme in the Environment, New York, USA, Marcel Dekker, 2002, pp. 171-225.

Chet I. Trichoderma - applications, mode of action and potential as a biocontrol agent of soilborne plant pathogenic fungi. In: Chet I (ed.), Innovative Approaches to Plant Diseases, New York, John Wiley \& Sons, 1987, pp. 137-160.

Chet I, Chernin L. Biocontrol, microbiol agents in soil. In: Bitton G (ed.), Encyclopedia of Environmental Microbiology, New York, USA, John Willey \& Sons Inc., 2002, pp. 450-465.

Cullen D, Andrews JH. (1984) Evidence for the role of antibiosis in the antagonism of Chaetomium globosum to the apple scab pathogen, Venturia inaequalis. Can J Bot 62:1819-1923.

Di Pietro A, Gut-Rella M, Pachlatko JP, Schinn FJ. (1992) Role of antibiotics produced by Chaetomium globosum in biocontrol of Pythium ultimum, a causal agent of damping-off. Phytopathology 82:131-135.

Di Pietro A, Lorito M, Hayes CK, Broadway RM, Harman GE. (1993) Endochitinases from Gliocladium virens: isolation, characterization, and synergistic antifungal activity in combination with gliotoxin. Phytopathology 83:308-313.

Elad Y, Chet I, Katan J. (1980) Trichoderma harzianum: a biocontrol agent effective against Sclerotium rolfsii and Rhizoctonia solani. Phytopathology 70:119-121.

Gao KX, Liu XG, Liu YH, Zhu TB, Wang SL. (2002) Potential of Trichoderma harzianum and T. atroviride to control Botryosphaeria berengeriana $\mathrm{f}$. sp. piricola, the cause of apple ring rot. J Phytopathol 150:271-276.

Gao KX, Liu XG, Li C, He BL, Wang QH. Biocontrol potential of Chaetomium spirale ND35 against canker of apple tree. In: Yang Q (ed.), Biological Control and Bio-technology, Harbin, Heilongjiang Science and Technology Press, 2003, pp. 132-140.

Gao KX, Liu XG, Friesem D, Chernin L, Shi CK. (2005) Cell wall degrading enzymes involved in mycoparasitism of the biocontrol agent Chaetomium spirale ND35. Sci Silvae Sinicae 41:205-210. 
Inbar J, Chet I. (1992) Biomimics of fungal cell-cell recognition by use of lectin-coated nylon fibers. J Bacteriol 174:1055-1059.

Kang Z, Buchenauer H. (2002) Immunocytochemical localization of $\beta$-1, 3-glucanase and chitinase in Fusarium culmorum-infected wheat spikes. Physiol Mol Plant Pathol 60:141-153.

Kang Z, Buchenauer H. (2003) Immunocytochemical localization of cell wall-bound thionins and hydroxyproline-rich glycoproteins in Fusarium culmorum-infected wheat spikes. J Phytopathol 151:120 129.

Kaushik JC, Sanjay A, Tribathi NN, Arya S. (2000) In vitro evaluation of fungal and bacterial antagonists against fungal pathogens causing damping off in forest nurseries. Indian Forester 126:885-889.

Knudsen IBM, Hockenhull J, Jensen DF. (1995) Biocontrol of seedling diseases of barley and wheat caused by Fusarium culmorum and Bipolaris sorokiniana: effects of selected fungal antagonists on growth and yield components. Plant Pathol 44:467-477.

Kohl J, Belanger RR, Fokkema NJ. (1997) Interaction of four antagonistic fungi with Botrytis aclada in dead onion leaves: a comparative microscopic and ultrastructural study. Phytopathology 87:634-642.

Liu XG, Gao KX, Gu JC, Du JL, Tang XG. (1999) Testing on the antagonism of the dominant of endophytic fungi from Populus tomentosa, Chaetomium ND35 in the laboratory. Sci Silvae Sinicae 35:57-61.

Lorito M, Woo SL, Ambrosio MD et al. (1996) Synergistic interaction between cell wall degrading enzymes and membrane affecting compounds. Mol Plant Microbe Interact 9:206-213.

Miosge N, Dresp W, Herken R. (1997) Ultrastructural localization of bind sites for the lectins RCA 1, WGA, and LTA in the preimplantation mouse embryo. J Histochem Cytochem 45:447-453.

Monaco CI, Rollan MC, Nico AI. (1998) The effect of mycoparasites on the reproductive ability of sclerotia of Sclerotinia sclerotiorum. Rev Iberoamericana Micol 15:81-84.
Northcote DH, Davey R, Lay J. (1989) Use of antisera to localize callose, xylan and arabinogalactan in the cell-plate, primary and secondary walls of plant cells. Planta 178:353-366.

Pereira J, Dhingra OD. (1997) Suppression of Diapothe phaseolorum f. sp. meridionalis in soybean stems by Chaetomium globosum. Plant Pathol 46:216-223.

Reissinger A, Winter S, Steckelbroeck S, Hartung W, Sikora RA. (2003) Infection of barley roots by Chaetomium globosum: evidence for a protective role of the exodermis. Mycol Res 107:1094-1102.

Rodriguez-Galvez E, Mendgen K. (1995) Cell wall synthesis in cotton roots after infection with Fusarium oxysporum. The deposition of callose, arabinogalactans, xyloglucans, and pectic components into walls, wall appositions, cell plates and plasmodesmata. Planta 197:535-545.

Schirmböck M, Lorito M, Wang YL et al. (1994) Parallel formation and synergism of hydrolytic enzymes and peptaibol antibiotics, molecular mechanisms involved in the antagonistic action of Trichoderma harzianum against phytopathogenic fungi. Appl Environ Microbiol 60:4364-4370.

Sudhamoy M, Srivastava KD, Rashmi A, Singh DV, Mandal S, Aggarwal R. (1999) Mycoparasitic action of some fungi on spot blotch pathogen (Drechslera sorokiniana) of wheat. Indian Phytopathol 52:39-43.

Vannacci G, Harman GE. (1987) Biocontrol of seed-born Alternalia raphani and A. brassicicola. Can J Microbiol 33:852-856.

Walther D, Gindrat D. (1988) Biological control of damping-off of sugarbeet and cotton with Chaetomium globosum or a fluorescent Pseudomonas sp. Can J Microbiol 34:631-637.

Winkler J, Lünsdorf H. (2001) Ultrastructure and composition of asteroid bodies. Invest Ophthalmol Vis Sci 42:902-907.

Yedidia I, Benhamou N, Chet I. (1999) Induction of defense responses in cucumber plants (Cucumis sativus L.) by the biocontrol agent Trichoderma harzianum. Appl Environ Microbiol 65:1061-1070. 